\title{
EA05
}

\section{A Synthesis of Petroleum Systems Offshore Mozambique}

\author{
E. Hollebeek* (Schlumberger GeoQuest), O. Osicki (Schlumberger PTS), D. \\ Kornpihl (Schlumberger PTS), T. West (Schlumberger PTS) \& S. Sarkar \\ (Schlumberger PTS)
}

\section{SUMMARY}

There has been renewed exploration interest in the Mozambique basin after recent gas discoveries in the offshore Rovuma basin. This study focuses on petroleum systems modeling of the entire offshore Mozambique basin. Recently acquired multiclient broadband 2D seismic data are used as the basis for a regional petroleum systems modeling study to analyze the potential for hydrocarbon generation, expulsion, and accumulation in the various basins of Mozambique. 2D seismic interpretation is combined with information on potential source, seal, and reservoir rocks to create $2 \mathrm{D}$ and $3 \mathrm{D}$ petroleum systems models. These models provide improved understanding of the exploration risks and targets of the area, and suggest that oil, as well as gas, is present offshore Mozambique. 


\section{Introduction}

There has been renewed exploration interest in the Mozambique basin after recent gas discoveries in the offshore Rovuma basin. This study focuses on petroleum systems modeling of the entire offshore Mozambique basin. Recently acquired multiclient broadband 2D seismic data are used as the basis for a regional petroleum systems modeling study to analyze the potential for hydrocarbon generation, expulsion, and accumulation in the various basins of Mozambique. 2D seismic interpretation is combined with information on potential source, seal, and reservoir rocks to create 2D and 3D petroleum systems models. These models provide improved understanding of the exploration risks and targets of the area, and suggest that oil, as well as gas, is present offshore Mozambique.

\section{Regional Setting}

The hydrocarbon potential of offshore Mozambique can be understood in terms of the tectonic history of the East African margin. The Mozambique basins formed during the Triassic-Jurassic rifting of Gondwanaland, followed by the southward motion of Madagascar along the Davie Ridge, which formed a set of north-south trending shear zones resulting in local extension, compression, and trap formation. Major source rock deposition occurred during the initial rift phase, in isolated grabens, and in the Late Jurassic sag period, when the basin remained highly restricted. Two Cretaceous stages of source rock deposition are believed to have occurred, associated with the Lower and Upper Domo formation, and a Tertiary anoxic interval is related to the organic-rich Grudja formation (Coster et al., 1989). These five source rock intervals are modeled to understand the petroleum systems in the offshore Mozambique basins.

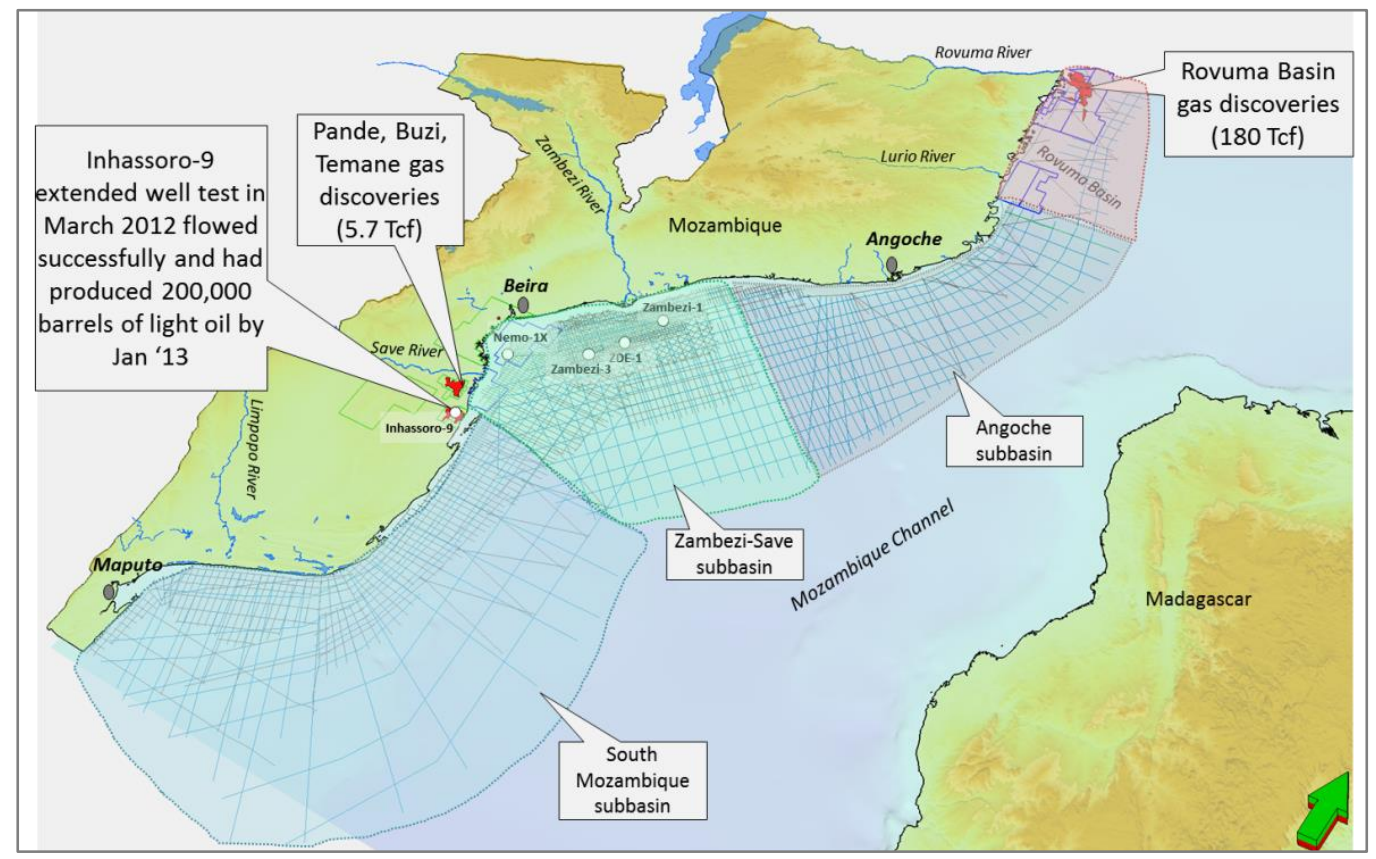

Figure 1 Overview of offshore Mozambique. Outline of new 2013 seismic survey in blue, brokered multiclient seismic surveys in grey, hydrocarbon fields in red, offshore current license blocks in dark blue, and onshore current license blocks in green. The four subbasins are highlighted.

The Mozambique offshore area can be divided into two basins, the Rovuma basin and Mozambique basin. These can be further subdivided into four major subbasins (Figure 1). The Rovuma basin, in the north, which is associated with the major offshore gas discoveries, is affected by tectonics related to the Davie Ridge creating different segments in the basin. To the south, the Mozambique basin includes the Angoche region, as well as the Zambezi-Save subbasin, which is separated by the Mozambique Ridge from the South Mozambique subbasin. 
This study analyses the similarities and differences in terms of hydrocarbon potential of these four subbasins in light of the petroleum systems modeling results.

\section{Petroleum Systems Modeling}

Petroleum systems modeling (PSM) has become a standard tool in hydrocarbon exploration. PSM is based on the petroleum systems concept (Magoon and Dow, 1994); this holistic approach complements the prevailing play concept. The petroleum systems concept incorporates the existence of an active source rock as a coequal element along with reservoir, seal, and trap, governed by the timing of generation, migration, accumulation, and trap formation. For this study, two 2D models are compiled from each of the four subbasins, as well as associated 3D models based on interpretation of seven horizons across the entire offshore area. The five source intervals are modeled to understand their likely transformation ratio, thermal profile, and vitrinite reflectance. The concept of a seal critical moment is also introduced. This depicts the moment in time when the seal of a postulated petroleum system becomes effective (at 1.2-MPa capillary entry pressure). The source rock critical moment and seal critical moment are compared to analyze if a source rock is likely to contribute charge to a trap.

\section{Results}

Across the four Mozambique offshore basins, PSM suggests that hydrocarbons are present in both liquid and vapor forms. Gas is more likely to be generated from Jurassic sources in deeply buried areas, due to both increased thermal maturity and secondary cracking. These areas include the deep Angoche region and rift grabens. Modeling indicates that large areas of all four basins have hydrocarbon potential, predominantly originating from the Jurassic syn-rift and sag phase source rocks. Younger Cretaceous sources are mature only in areas with higher overburden, particularly the deep Angoche basin and the Zambezi-Save area. These Cretaceous source rocks reach their critical moment later, therefore it is likely they expel hydrocarbons after the seal has reached sufficient pressure. For older source rocks, expulsion is earlier, so Jurassic and early-Cretaceous seals are the only seals that will have reached sufficient pressure at the source critical moment. Cretaceous seals are likely to have reached sufficient pressure only at the time of secondary cracking, or in those areas where the Cretaceous source rocks are mature, in the Angoche and Zambezi-Save basins. PSM also indicates the importance of local tectonic events and associated structures, such as the Davie Ridge, Beira High, and Xai-Xai Graben, in affecting the burial history and maturity of the local source rocks.

\section{Conclusion}

The synthesis of eight 2D models and associated 3D models based on seismic interpretation of seismic data offshore Mozambique indicates the hydrocarbon potential across the area. The Jurassic syn-rift and sag phase source rocks have reached sufficient transformation ratios for expulsion in almost all areas. Trends can be identified in the four basins, suggesting that Jurassic source rocks are more likely to be producing oil in the Rovuma ultradeep and southern Mozambique basins, whereas Cretaceous sources are likely to lie in the oil window in the Zambezi-Save and Angoche regions. The concept of seal timing is introduced to the modeling, revealing regions where the relative timing of source and seal is favorable. Comparison of petroleum systems models across the entire offshore Mozambique region therefore illustrates the variability within and between the four major basins, and illuminates in more detail the hydrocarbon potential of this vast area.

\section{Acknowledgements}

We would like to thank Schlumberger Multiclient for the use of the seismic data.

\section{References}

Coster, P.W., Lawrence, S.R., and Fortes, G. [1989] Mozambique: a new geological framework for hydrocarbon exploration. Journal of Petroleum Geology, 12(2), 205-230.

Magoon, L.B. and Dow, W.G. [1997] The Petroleum System-From Source to Trap. AAPG Memoir, 60, 655 . 